\title{
腫瘍組織のエステラーゼ・アイソザイム分析
}

1. 脂肪肉腫を中心として

九大整形外科

貝原 信 紘・江口正 雄

柴 田堅一郎・篠 原 典 夫

別 府 保 男

\section{Electrophoretic Separation of Esterase Isozymes in Tumor Tissues}

1. Isozyme Pattern of Liposarcoma.

By

\author{
N. Kaibara, M. Eguchi, K. Shibata, \\ N. Shinohara and Y. Beppu \\ Department of Orthopaedic Surgery, Faculty of Medicine, \\ Kyushu University, Fukuoka.
}

\begin{abstract}
Esterase isozymes were studied in the extracts of bone and soft parts tumors. The isozymes were extracted with $0.25 \mathrm{M}$ sucrose solution and separated on polyacrylamide gel according to Tomino et al. Esterase activity was detected in the polyacrylamide gels by the method using $\alpha$-naphthyl acetate and hexazotized pararosaniline.

In the tissue varieties examined, a composite total of 12 discrete esterase bands were discerned.

The extracts of three specimens of lipomas revealed the same isozyme pattern as normal adipose tissue. In the extracts of three liposarcomas, the isozyme pattern showed greater heterogeneity.
\end{abstract}

\section{はじめに}

アイソザイムの概念は現在遗伝学上の問題解明への 1 手段として広く応用されているが, 腫㻛との関係に おいでも主として癌化の過程におけるアイソザイムパ ターンの変化, あるいは悪性腫焬に共通するアイソザ イムパターンが存在するか否か等の問題において広く 研究されている.しかし整形外科領域における骨軟部 腫焬とアイソザイムの 問題に 関しては 乳酸脱水素醉 素, アルカリフォスファターゼ, 酸フォスファターゼ に関する研究が散見されるのみである．酸フォスファ ターゼアイソザイムについてはわれわれがすでに詳し く報告しているが，必ずしも覀性腫瘍に共通するアイ ソザイムパターンは存在せず，骨巨細胞腫, fibrous dysplasia, 骨肉腫, 骨転移癌, 線維肉腫については それぞれ特有なアイソザイムパターンが存在するとと が明かであった．てれらの結果から腫焬の形態学的診 断に加えて新たに有力な補助彰断法としての䣼素学的 診断の可能性が示唆される. 今回われわれは nonspecific esterase を取り上げて腫煬組織中の本醭素の質 的検討を行なっているので脂肪肉腫を中心として報告 する.

\section{材料および方法}

手術あるいは剖検時に採取した腫瘍組織を用いた。 採取した腫瑒組織は生理的食塩水で軽く洗って付着せ る血液成分を除き，明かな腫瘍塊のみを $-20^{\circ} \mathrm{C} に て$ 凍結保存し, 適宜実験に供した。 
凍結保存せる腫煌組織約 $200 \mathrm{mg}$ 亿 $0.25 \mathrm{M}$ sucrose を加え, ガラスホモジナイザーを用いて氷冷下 に $10 \%$ のモジネートを作製し，冷凍遠心 10,000X $\mathrm{g}, 15$ 分間の上清を試料とした。

アイソザイムの分髉は Clarke, Tomino らの報告 によるアクリルアミドゲル電気泳動法を若干 modify して行なった。 ゲル浱度は $7.5 \%$ とし, gelling buffer は Tomino らの方法に従って調製した. 分離用 ゲルの上に直接 10 30 $\mu 1$ の試料をのせ，上下の電極 槽には Tris-glycine-HCl 緩衝液 $\mathrm{pH} 8.1$ を各 500 $\mathrm{m} 1$ 使用した. $4^{\circ} \mathrm{C}$ の冷室中にて $300 \mathrm{~V}$ の定電圧で 90 分間泳動した。泳動終了後ゲルをガラス管より取り出 し， $\alpha$-naphthyl acetate 基質とした hexazotized pararosaniline との混液により室温にて 30〜60分 間活性染色を施した. back-ground staining をでき るだけ少くする目的で塩酸パラロザニリンは $1 / 6$ 量に 減量して用いた. 各活性帯の分画比は densitomaster Kemic を用いて測定した.

結果

種々の陚料について得られた各活性带を合成して模 式的に示すと図1のようになる。各活性带は易動度の 大なるもの，易動度の小なるもの，その中間のものと 3 群飞大別可能であり, それぞれ fast (F), slow (S), intermediate (I) と便宜的に表現した。活性帯 $S$ は更に 10 の分画に細分され，それぞれ $S_{1}$ から $S_{10}$ と仮称して表現した，他方活性帯F は少くとも3 個の 分画に分れるようであるが，Sにみられるでとくシャ 一プに分離されなかったため今回はこれら 3 個の分画 を合せてF分画と呼ぶことにした。

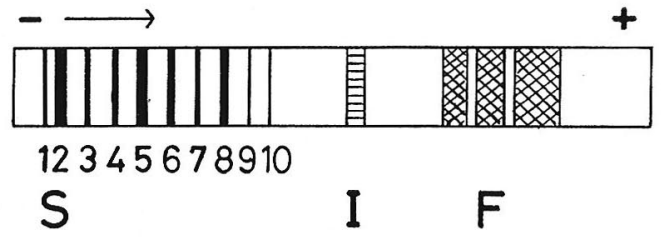

図1エステラーゼアイソザイムのシェーマ

正常脂肺組織および脂䏳腫のエステラーゼザイモグ ラムを図 2 に示した。 まず正常脂肪組織においては $\mathrm{S}_{5}$ に強いエステラーゼ活性があり，乙れより易動度 そ増すにつれて活性は渐次娍弱していく， $\mathrm{S}_{2}, \mathrm{~F}$ 分画 には非常に弱い活性が認められるが， $\mathrm{S}_{3}, \mathrm{~S}_{4}$ 分画には 活性を検出するととができなかった。

次に脂肪腫のザイモグラムをみてみると正常脂肪組 織と同様に $\mathrm{S}_{5}$ 分画に主活性があり， $\mathrm{S}_{6}, 7,8,9,10$ と䉼 次活性が減弱していく. $\mathrm{S}_{2}, \mathrm{~F}$ 分画は活性が非常に弱 い.とのアイソザイムパターンは正常脂肪組織のもの とまったく同じである. 脂肪腫についてはとのほか2 例について検索したが，アイソザイムパターンは類似 のものであった.

次に脂肪肉腫 3 例について得られた結果を図 3 亿示 した。 症例 1 は $\mathrm{F}$ 分画に主活性があり， $\mathrm{S}_{2}$ 分画に中 等度の活性が認められた。 $\mathrm{S}_{3}, \mathrm{~S}_{4}, \mathrm{~S}_{5}$ 分画画には非常 に弱い活性が検出されたが，その他の分画には活性 を検出するととができなかった，病理組織学的には myxoid type の脂肪肉腫であった。

症例 2 は $\mathrm{S}_{2}$ 分画に主活性があり, $\mathrm{F}$ 分画は 2 分画 に分雄されているが活性は中等度である．次いで $\mathrm{S}_{5}$ 分画に中等度の活性が検出された。その他の分画には 活性を検出できないか検出されても㥛婂て弱い活性で

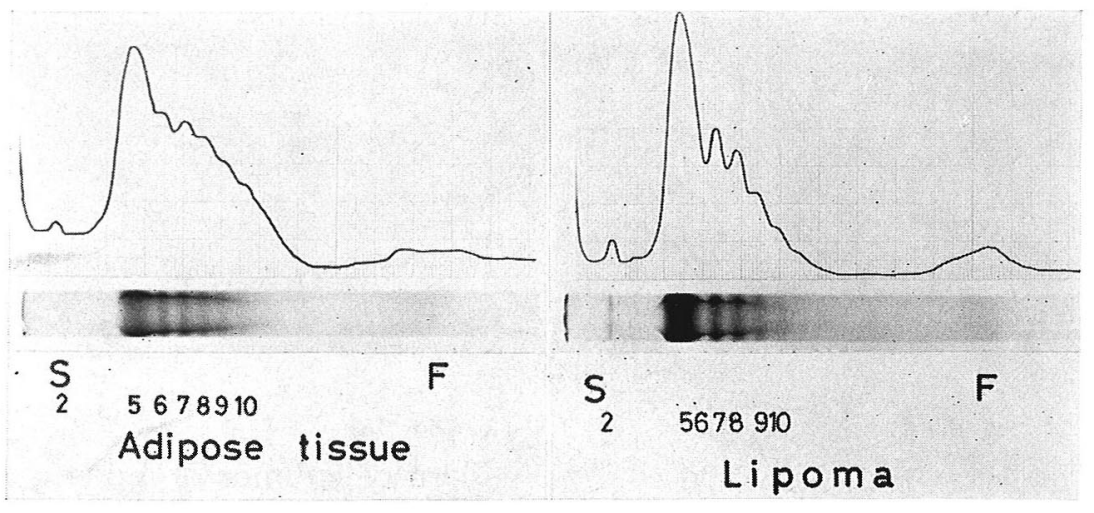

図 2 正常脂肪組織と脂肪腫のザイモグラムとデンシトメトリー 

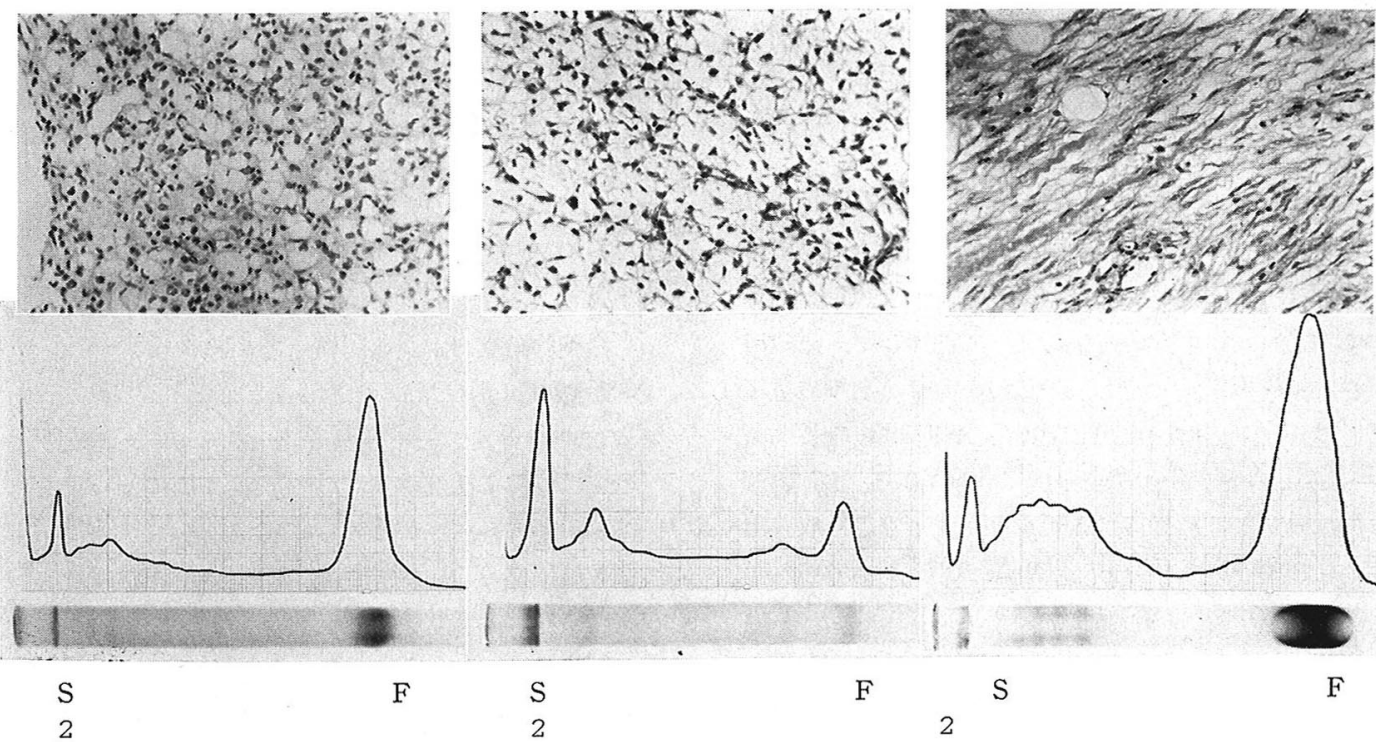

Liposarcoma 1

$\mathrm{S}$

2

Liposarcoma 2

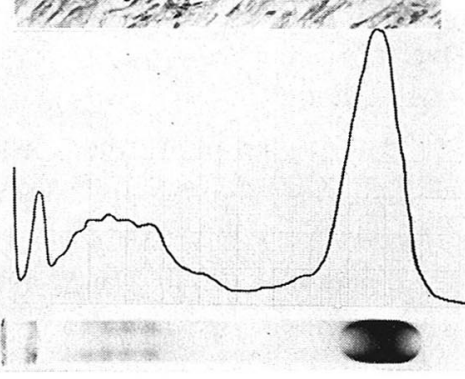

S

F

Liposarcoma 3

図 3 脂肪肉腫 3 例のザイこグラムと組織像

あった. 病理組織学的とは myxoid type の脂肪肉腫 であった，以上 2 例はともに myxoid type の脂肪肉 腫であり, ザイモグラムにて $\mathrm{S}_{2}$ 分画と $\mathrm{F}$ 分画の活性 比が逆転してはいるが，比較的強い活性はこの 2 分画 に限られている. 次いで $\mathrm{S}_{5}$ 分画に少し弱い活性がみ られるが，その他の分画は活性が検出されないか，検 出されても極めて弱いという点で共通のパターンであ った.

症例 3 は F 分画に非常に強い活性があり, 次いで $\mathrm{S}_{2}$ 分画, さらに $\mathrm{S}_{5}, \mathrm{~S}_{6}, \mathrm{~S}_{7}, \mathrm{~S}_{8}$ 分画に同程度の弱い活 性が検出され， $\mathrm{S}_{3}, \mathrm{~S}_{4}$ 分画は極めて 弱い活性であっ た. 病理組織学的には fibrosing type の脂肪肉腫で あった。とのアイソザイムパターン注㭪する骨巨細
胞腫や線維肉腫のアイソザイムパターンに近似したも のであり，症例 1，2亿みられた myxoid type の脂 肪肉腫のアイソザイムパターンとは明が異質のもの である。

骨巨細胞腫と線維肉腫の各 1 例について得えれた結 果を以上述べてきた脂肪組織由来の腫瘍で得られた結 果と対比させる目的でまとめて図 4 亿示した。骨目細 胞腫においては $\mathrm{F}$ 分画に主活性があり, 次いで $\mathrm{S}_{2}$ 分 画に比較的強い活性がある. $\mathrm{S}_{3}$ 汃ら $\mathrm{S}_{8}$ 分画はほぼ同 程度の活性を有し, 前述の fibrosing type の脂肪肉 腫に近似したパターンである。

線維肉腫のザイモグラムも一見して骨巨細胞腫や fibrosing type の脂肪肉腫によく似たパターンを示

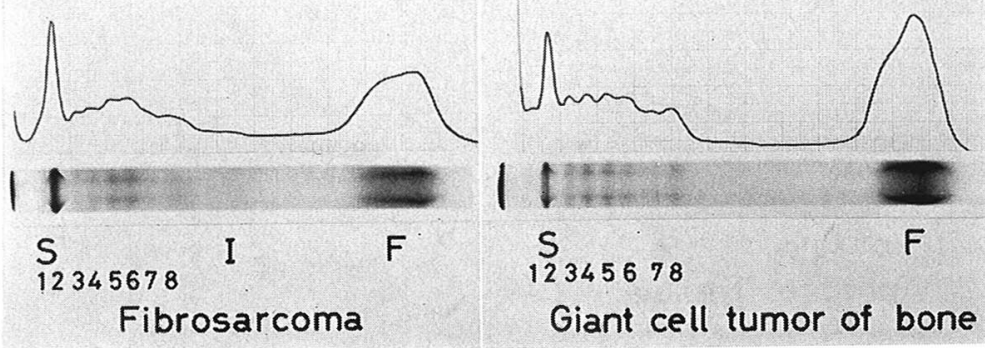

図 4 線維肉腫と骨巨細胞腫のザイモグラム 
しているが, $\mathrm{S}_{2}$ 分画が比較的強く，また活性は弱い が I 分画が検出されている点でてれらとはまったく異 るパターンということができる.

\section{考察}

エステラーゼが単一の醳素䧺白でなく，アイソザイ ムが存在することは周知の事実である.アイソザイム の分析には電気泳動法を用いるととが多いが，使用さ れる支持体, 緩衝液その他の泳動条件により, 得られ たザイモグラムに違いが生じるととも当然である. 令 回われわれがアクリルアミドゲルを支持体とした電気 泳動法によるエステラーゼアイソザイムの分析を試み るととに法めたのは，（1）試料が極く微量でよい, （2）操作が手軽である，(3) 再現性がよい，(4) 分離能が優れている，などの理由による.

種々の条件によるアクリルアミドゲル電気泳動法に ついて検討を加えた結果, Clarke 法を若干 modify した Tomino らの房法が最も分離能がよいのでての 方法をさらに少し modifyして利用することにした. 本法の再現性は極めて良好であった。

次には使用する基質の問題が生じてくるが，今回は $\alpha$-naphthyl acetate, $\beta$-naphthyl acetate, naphthol AS acetate および naphthol AS-D chloroacetate を用いて検討した. その結果 $\alpha$-naphthyl acetate を用いた場合に最も安定した活性染色が得ら れたので今回の報告はすべて $\alpha$-naphthyl acetate を基質としたものである.

本法によるとエステラーゼは少くとも 12 個の分画 に分離可能であり, $S_{1} \sim S_{10}, I, F$ 分画と仮称して表 現した.

正常脂肪組織と脂肪腫では $\mathrm{S}_{5}$ 分画に主活性があり, てれより易動度が大なる分画では渐次活性は減弱して いく. $\mathrm{S}_{2}$ と F分画の活性は非常に弱く，ともに同一 のパターンであった. 脂肪肉腫 3 例については正常脂 肪組織や脂肪腫でみられたアイソザイムパターンとは 全く異るパターンが認められた。ささらに同じ脂肪肉腫 の中でもタイプが異ればアイソザイムパターンも逵い が生じるてとも明かとなった。

脂肪肉腫を含めて整形外科領域における骨軟部腫煌 のエステラーゼアイソザイムに関する報告は残念なが ら見当らない. 実験腫瘍についてみれば Kreusser は ハムスターの正常および腫煬組織のエステラーゼアイ ソザイムを検索して正常組織には㖑器特異性を有する
アイソザイムパターンを誌めているが，悪性腫婸のア イソザイムパターンはわずかの例外を除いて母組織と は全く巽る一定の tumor pattern に近ずくと報告し ている.

Yoshimura はマウスを用いて皮膚および唾液腺の 癌化の過程におけるアイソザイムパターンの変化を調 へ，脱分化による一定の tumor pattern への移行を 認めている。乙れらは共に Greenstein の法則を支持 する結果である．他方 Young らはヒトの悪性腫煬が 必ずしも一定のエステラーゼアイソザイムパターンを 示さないと報告しており，果して Greenstein の法則 が成立するのか否かについても㶬だ結論の出せない状 態である.

われわれが酸フォスファターゼアイソザイムについ て調べた結果でも必ずしも悪性腫焬に共通するtumor pattern は認められず, 数種の腫瘍群についてはそれ ぞれ特有なアイソザイムパターンが諗められた。

このことは翻って考えてみるとアイソザイムパター ンの検索から腫瘍診断の可能性が生れることを示唆す るものである.今後さらに症例を積み重ねて腫瘍の酵 素学的診断の可能性を更に追求していく予定である.

\section{結語}

エステラーゼアイソザイムの分析法について述べ, 腫瘍組織中のエステラーゼアイソザイムを検索するて との意義について考察を加えた。

\section{文献}

1) Clarke, J. T. Ann. N. Y. Acad. Sci., 121 : 428, 1964.

2）江口正雄ほか，骨代謝，6：135，1973.

3) 貝原信紘, 福岡医誌, 66:397, 1975.

4) Kreusser, E. H. Cancer Res., 26: 2181, 1966.

5) Tomino, S., \& Paigen, K. In the Lactose Operon (Beckwith, J. R., \& Ziper, D., eds.), p. 233, Cold Spring Harbor Laboratory, Cold Spring Harbor, New York, 1970.

6) Yoshimura, Y. Gann, 62: 187, 1971.

7) Young, C. W., \& Bittar, E. S. Cancer Res., $33: 2692,1973$.

澌問北里大学 真 角

(1) 正常脂肪と肉腫組織との間のパターンの違いは 興味深い.ただ分画の再現性, 恒常性はよろしいでし 
ょうか.

(2) Chemical Biopsy の意味で, 実際に臨床に応 用されていますか?，臨床的意義についてはいかがで しょう。

問鳥取整形 前山篇

各腫場によるアイソザイムパターンの意義づけにつ いて，何か知見をおもちでしょうか.

\title{
良 性 軟 骨 芽 細 胞 腫 の 5 例
}

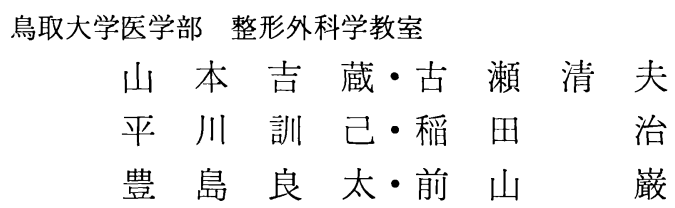

\section{Five Cases of Benign Chondroblastoma}

By

\author{
K. Yamamoto, K. Furuse, K. Hirakawa, \\ O. Inata, R. Teshima and I. Maeyama.
}

Department of Orthopaedic Surgery, Tottori

University School of Medicine

\begin{abstract}
Five cases of benign chondroblastoma were presented in this report. Three cases had tibial involvement, talus and pubis was also affected in each one case. Four males and one female. The age range was 12 to 28 years.

Histologically, tumors were consist of oval chondroblasts and giant cells with cartilage matrix, stained slightly with Alcian blue.

The ultrastructures of chondroblast and cartilage matix were studied utilizing TEM and SEM. The well developed and sometimes dilated endoplamic reticulums and filaments in the cytoplasm were characteristic and also, protein-mucopolysaccharide was detected by PAM staining. By energy dispersive analysis of X-ray, apatite clusters with 0.5 to $0.8 \mu$ in diameter in tumor matrix showed a little different patterns of $\mathrm{Ca}, \mathrm{P}$ and $\mathrm{S}$ from the epiphyseal cartilage matrix.
\end{abstract}

Benign chondroblastoma は, 最初 giant cell tumor の 1 異型と考えられ， calcifying giant cell tumor, epiphyseal chondromatous giant cell tumor また cartilage containing giant cell tumor などと呼ばれていた。 1942 年 Jaffe \& Lichtenstein が組織学的検索をもとに benign chondroblastoma と命名し，以後，広く使用をされるように なった。

昭和 39 49 年までの 11 年間のわが国骨腫煬全国登 録によると，64 例が 登録されているにすぎず，比較 的まれな疾患である.
最近, われわれの教室で 5 例の本症を 経験したの で, その臨床像, 組織学的検索結果について報告し, 全国登録症例と比較検討を加える.

$$
\text { 症例 }
$$

症例は, 距骨 1 例, 脛骨 3 例および恥骨 1 例の計 5 例（表 1) で, 年令は 12 才から 26 才までの比較的若 い人に限られ，男 4 例，女1例であった。

1 ）エックス線像

一般に境界の明晻な骨透明楽として認められ, 円形 ないし楕円形で, 辺縁部は薄い骨硬化像を呈する. 症 